\title{
The emergence and development of mycoses in short-day plants under conditions of long daylight hours
}

\author{
Igor Podkovyrov ${ }^{1, *}$, Oybek Kimsanbaev ${ }^{2}$, Natalya Zhemchuzhina ${ }^{1}$, Dmitry Ermak ${ }^{1}$, \\ Laura Ilyusinova ${ }^{2}$, and Tatiana Nasonova ${ }^{2}$ \\ ${ }^{1}$ All Russian Research Institute of Phytopathology, Moscow Region 143050, Russia \\ ${ }^{2}$ Volgograd State Agrarian University, Volgograd, 400002, Russia
}

\begin{abstract}
The relevance of the study of mycoses is increasing due to their widespread distribution. Field experiments were carried out on sites in the region with short daylight hours (Dagestan) and long daylight hours (Volgograd). Fungal diseases were investigated on crops with short daylight hours: cucumber, pepper, and cotton according to the methods generally accepted in phytopathology. The species composition of aboriginal and exotic infections was revealed. Each culture under conditions of long daylight hours is characterized by damage by $4-5$ species of fungi. The manifestation of exotic infections is observed at the beginning of the growing season at the seedling stage. The role of the introduction of short-day plants to the northern regions in the spread of exotic species of pathogenic fungi is shown. The species composition of fungi on crops in the study areas was found to be identical. They belong to different biological groups, but saprotrophs, biotrophs and hemibiotrophs predominate. It was found that Fusarium lolii (Wm.G. Sm.) Sacc and Rhizoctonia solani Kuehn (on cotton) and Verticillium dahliae Kleb and Rhizoctonia solani J.G. moved to new areas together with seeds. Kuhn (on pepper). These species are capable of causing epiphytotics at the beginning of the growing season with a low natural infectious background. The accumulation of native species of infection in the lands adjacent to the fields during the cultivation period leads to the appearance of epiphytoties in the second half of the growing season. First of all, the assimilation apparatus, flowers, ovaries and fruits are affected.
\end{abstract}

\section{Introduction}

The Food and Agriculture Organization of the United Nations has declared 2020 the International Year of Plant Health to highlight the fight against hunger, poverty, protect the environment and accelerate economic development [5]. In this regard, the relevance of scientific research in the field of plant protection, reducing the pesticide load on agricultural landscapes for the production of organic and environmentally friendly products has increased many times. For the conditions of the Lower Volga region, this direction of

\footnotetext{
${ }^{*}$ Corresponding author: parmelia@mail.ru
} 
research is new, since most of the enterprises use traditional systems of chemical protection $[3]$.

The advancement of crops with short daylight hours to the northern growing regions led to the emergence of epiphytoties of fungal infections that reduce productivity and product quality $[1,8]$. Changing the light regime when growing plants leads to disturbances in the natural rhythms of development and a decrease in resistance [9].

This provokes the emergence and development of fungal infections, primarily on the root system, leaves and shoots [10]. The fungi move to new areas with the seeds, seedlings and seedlings of host plants [6]. If in the XVII-XVIII centuries spontaneous introduction took place from one continent to another, then in the modern world the role of migration of pathogenic organisms from south to north has increased [4]. The study of the ways and mechanisms of their distribution along with agricultural crops in new regions is of both theoretical and practical interest. This topic is especially relevant for predicting invasions, developing new methods of plant protection and ensuring food security of states [2].

Practice has shown the possibility of adapting pathogenic fungi to new areas of their life. This process is facilitated by climatic changes occurring on the planet. As a result of the high anthropogenic load on agricultural landscapes, useful microflora disappears. Its place is taken by microorganisms that cause plant diseases. Many endemic species of fungi successfully migrated to new areas and caused massive plant deaths [7].

One example is the spread of the fungus Ophiostoma ulmi together with the introduction of the elm elm from China to the American and European continents. As a result, the endemic fungus caused the mass death of natural elm forests in the United States of America, Holland, Russia and other countries.

The aim of the research is to study the development of fungal diseases in plants with short daylight hours under conditions of introduction when changing the lighting regime.

\section{Objects and technique}

Plants with a well-pronounced photoperiodic response were selected as model crops. In the open ground, experimental studies were carried out on bell pepper (Volzhanin variety) and cotton (PGSSKh 1), and in greenhouses on cucumber (Athlet $\mathrm{F}_{1}$ hybrid). For these cultures, the defeat of mycoses is a characteristic feature. The varieties selected for the study are genetically susceptible to fungal attack. Diseases in plants develop on vegetative and generative organs.

Field experiments in the open field were carried out in areas with different daylight hours: the Republic of Dagestan (Kayakent) and the Volgograd region (Svetloyarsk district) against a natural infectious background. In protected ground, cucumber plants were examined in the greenhouse complex of the State Unitary Enterprise VOSHP Zarya, Volgograd Region. In the experimental plots, the growth and development of plants, the emergence and spread of fungal diseases, the nature of their course were observed. The scheme of the experiment included studies of the occurrence and development of mycoses on selected crops under conditions of long (Volgograd region) and short (Republic of Dagestan) daylight hours.

Vegetation experiments on growing plants against an artificial infectious background were carried out in the greenhouse of the Volgograd State Agrarian University. When setting up the experiments, the methodology generally accepted in phytopathology was used, taking into account the recommendations of B.A. Dospekhova (1985) and Z.I. Zhurbitsky (1968). Isolation of pure cultures of fungi and determination of their species were carried out in the laboratory of the All-Russian Scientific Research Institute of Phytopathology. 


\section{Results and discussion}

The area of cultivation of short-day crops has expanded significantly due to the appearance of new varieties created for northern latitudes. Breeding in the direction of shortening the growing season made it possible to promote crops such as sunflower, tomato, pepper, cucumber, cotton, and others in latitudes with long daylight hours. The introduction of plants in new growing areas in the 19th century made it possible to avoid the occurrence of disease epiphytoties. Their pathogens did not develop in uncharacteristic soil and climatic conditions. The phytosanitary state of the crops of the introduced crops was much better in comparison with the aboriginal ones. However, the ongoing climatic changes lead to a change in the thermal regime of territories with long daylight hours. This led to an increase in the survival rate of pathogenic organisms in conditions unusual for them.

The advancement of new crops to relatively northern regions led to the emergence of adaptations in parasitic fungi. The ongoing process of plant introduction together with pathogenic organisms leads to a deterioration of the phytosanitary situation in crops and soil. Traditional technologies for the production of crop products do not take these features into account. This circumstance reduces the effectiveness of plant protection used at enterprises. The problem is solved by increasing the amount of applied fungicides. However, such decisions have a short-term effect. Therefore, epiphytoties in crops are repeated with high frequency.

Analysis of the diversity of fungi in three crops showed that species that damage leaves and roots predominate (Table 1).

Table 1. Types of pathogenic fungi causing mycoses in short-day plants.

\begin{tabular}{|c|c|c|c|}
\hline Plants & Types of pathogenic fungi & $\begin{array}{l}\text { Affected } \\
\text { organs }\end{array}$ & $\begin{array}{l}\text { Biological } \\
\text { group }\end{array}$ \\
\hline \multirow{4}{*}{$\begin{array}{l}\text { Cucumis } \\
\text { sativus }\end{array}$} & Pseudoperonospora cubensis Rostowz & leaf & biotroph \\
\hline & $\begin{array}{l}\text { Erysiphe cichoracearum DC.f. } \\
\text { cucurbitacearum Pot. }\end{array}$ & leaf & $\begin{array}{l}\text { obligate } \\
\text { parasite }\end{array}$ \\
\hline & $\begin{array}{c}\text { Colletotrichum lagenarium (Pass.) Ell. } \\
\text { et Halst. }\end{array}$ & leaf, fruit & $\begin{array}{l}\text { facultative } \\
\text { parasite }\end{array}$ \\
\hline & $\begin{array}{c}\text { Fusarium oxysporum f.sp. } \\
\text { cucumerinum }\end{array}$ & root & $\begin{array}{l}\text { facultative } \\
\text { parasite }\end{array}$ \\
\hline \multirow[t]{5}{*}{$\begin{array}{l}\text { Capsicum } \\
\text { annuum }\end{array}$} & $\begin{array}{c}\text { Fusarium oxysporum f. sp. Radicis- } \\
\text { lycopersici }\end{array}$ & root & $\begin{array}{l}\text { facultative } \\
\text { parasite }\end{array}$ \\
\hline & Verticillium dahliae Kleb & root & saprotroph \\
\hline & Rhizoctonia solani J.G. Kuhn & root & hemibiotroph \\
\hline & Alternaria solani Sor & fruit & hemibiotroph \\
\hline & Leveillula taurica (Lev.) G. Arnaud & leaf & biotrophic \\
\hline \multirow{5}{*}{$\begin{array}{l}\text { Gossypium } \\
\text { hirsutum }\end{array}$} & Rhizoctonia solani Kuehn & root & hemibiotroph \\
\hline & Fusarium lolii (Wm.G. Sm.) Sacc. & root & saprotroph \\
\hline & Fusarium oxysporum Schltdl & root & saprotroph \\
\hline & Alternaria macrospora Zimm. & leaf & saprotroph \\
\hline & $\begin{array}{l}\text { Bipolaris sorokiniana }(\text { Sacc.) } \\
\text { Shoemaker } \\
\end{array}$ & leaf & hemibiotroph \\
\hline
\end{tabular}

By the type of parasitism, the identified types of pathogenic fungi belong to different biological groups. However, Fusarium oxysporum appears as a facultative parasite on cucumber and pepper, and as a saprotroph on cotton. The root system is damaged, as a rule, by saprotrophs and hemibiotrophs. These types of fungi settle on weakened plants and kill them. The further development cycle takes place on dead organs. Biotrophs settle on leaves (for example, Pseudoperonospora cubensis). Facultative parasites can develop on different organs. 
The life cycle of parasitic fungi is closely related to the host plants. The dynamics of the phases of seasonal development largely depends on the photoperiodic response. In conditions of long daylight hours, the growing season is shortened. There is a shift in the phases of flowering and fruiting in time to a later date. Infection and spread of pathogenic fungi also occur at different times of the season. The greatest similarity in the course of diseases is observed during the period of seed germination and seedling development. At this time, root diseases occur, which cause Fusarium, Rhizoctonia, Verticillium (table 2).

Table 2. Influence of day length on plant development and spread of pathogenic fungi.

\begin{tabular}{|c|c|c|c|}
\hline \multirow[b]{2}{*}{$\begin{array}{l}\text { Development } \\
\text { phase }\end{array}$} & \multicolumn{2}{|c|}{ Time of course } & \multirow[b]{2}{*}{$\begin{array}{l}\text { The predominant type of fung } \\
\text { on plants }\end{array}$} \\
\hline & $\begin{array}{l}\text { Prevailing species } \\
\text { of fungi on plants } \\
\text { in a long day } \\
\text { (Volgograd) }\end{array}$ & $\begin{array}{l}\text { in a short day } \\
\text { (Dagestan) }\end{array}$ & \\
\hline 1 & 2 & 3 & 4 \\
\hline \multicolumn{4}{|c|}{ Cucumis sativus } \\
\hline Seedling & April 20-May & 01 April 05-12 & $\begin{array}{c}\text { Fusarium oxysporum f.sp. } \\
\text { cucumerinum }\end{array}$ \\
\hline Vegetation & 02-15 May & 13-25 April & $\begin{array}{c}\text { Pseudoperonospora cubensis } \\
\text { Rostowz }\end{array}$ \\
\hline Budding & 16-23 May & 26 April-05 May & $\begin{array}{l}\text { Pseudoperonospora cubensis } \\
\text { Rostowz }\end{array}$ \\
\hline Bloom & 24 May-26 June & 06 May-15 June & $\begin{array}{c}\text { Erysiphe cichoracearum DC.f } \\
\text { cucurbitacearum Pot. }\end{array}$ \\
\hline Fruiting & May 29-June 30 & May 11-June 20 & $\begin{array}{c}\text { Colletotrichum } \\
\text { lagenarium (Pass.) Ell. et } \\
\text { Halst. и Erysiphe } \\
\text { cichoracearum DC.f. } \\
\text { cucurbitacearum Pot. }\end{array}$ \\
\hline \multicolumn{4}{|c|}{ Capsicum annuum } \\
\hline Seedling & 20 March-10 & 10 March-30 April & $\begin{array}{l}\text { Verticillium dahliae Kleb и } \\
\text { Rhizoctonia solani J.G. Kuhn }\end{array}$ \\
\hline Vegetation & $\begin{array}{l}\text { May } 11 \text { May-05 } \\
\text { June } \\
\end{array}$ & 01 May-20 May & $\begin{array}{c}\text { Verticillium dahliae Kleb и } \\
\text { Rhizoctonia solani J.G. Kuhn }\end{array}$ \\
\hline Budding & 06 June-20 June & 21 May-05 June & $\begin{array}{c}\text { Leveillula taurica (Lev.) G. } \\
\text { Arnaud }\end{array}$ \\
\hline Bloom & $\begin{array}{l}\text { June 21-August } 30 \\
\text { July }\end{array}$ & June 06-August 30 & $\begin{array}{c}\text { Leveillula taurica (Lev.) G. } \\
\text { Arnaud }\end{array}$ \\
\hline 1 & 2 & 3 & 4 \\
\hline Fruiting & 21-September 20 & $\begin{array}{l}\text { July 06-September } \\
25\end{array}$ & $\begin{array}{l}\text { Fusarium oxysporum f. sp. } \\
\text { Radicis-lycopersici и } \\
\text { Alternaria solani Sor }\end{array}$ \\
\hline \multicolumn{4}{|c|}{ Gossypium hirsutum } \\
\hline Seedling & May $10-25$ & April 30-May 12 & $\begin{array}{c}\text { Fusarium lolii (Wm.G. Sm.) } \\
\text { Sacc. и Rhizoctonia solani } \\
\text { Kuehn }\end{array}$ \\
\hline Vegetation & May 26-June 20 & May 13-June 10 & $\begin{array}{c}\text { Fusarium lolii (Wm.G. Sm.) } \\
\text { Sacc. }\end{array}$ \\
\hline Budding & June 21-July 10 & June 11-June 25 & Alternaria macrospora Zimm. \\
\hline Bloom & July 11-August 20 & June 26-August 15 & Alternaria macrospora Zimm. \\
\hline Fruiting & $\begin{array}{c}\text { August 21- } \\
\text { September 20 }\end{array}$ & $\begin{array}{c}\text { August 16- } \\
\text { September 05 }\end{array}$ & Fusarium oxysporum Schltdl \\
\hline
\end{tabular}


There is a similarity in the species composition of pathogenic organisms, on plants under conditions of long and short daylight hours. The occurrence of diseases is timed to the phases of development of agricultural crops. The timing of the appearance of infection on plants varies depending on the geographic location of the field. In the southern regions this happens 10-15 days earlier. During the growing season, there is a complex infection caused by 4-5 types of fungi. In the process of development, they replace each other and can act together. Such manifestations were noted on cucumber and pepper plants during the fruiting period. At this stage of development, plants are most vulnerable.

At the seedling stage, plants are also most susceptible to attack by two types of fungi. Such examples are found in cotton crops and pepper seedlings. They appear as root rot Fusarium lolii (Wm.G. Sm.) Sacc and Rhizoctonia solani Kuehn (on cotton) and Verticillium dahliae Kleb and Rhizoctonia solani J.G. Coon (on pepper). The spread of these pathogenic fungi in areas with private daylight hours using seeds for infected seeds. Of the identified pathogenic fungi with long daylight hours, these species are exotic. Also to this group by the group Colletotrichum lagenarium (Pass.) Ell. et Halst., Alternaria solani Sor and Pseudoperonospora cubensis Rostowz. These species of mushrooms have expanded their habitat along with the cultivated crops.

Aboriginal mycomycete species appear during flowering and fruiting. They are used in the second half of the growing season when daylight hours are reduced. The species Fusarium oxysporum Schltdl, Leveillula taurica (Lev.) G. Arnaud, Erysiphe cichoracearum DC are common on plants of the natural flora, from which you can switch to crops. Wellformed bushes are necessary for their full development. The stress caused by changes in the weather leads to a decrease in plant resistance. Against this background, infections spread in crops.

Stress manifestations in short-day plants in the northern part of the cultivation area occur 2.7 times more often. This is due to both the light regime and the characteristics of metabolism. The absence of a light signal for rapid growth at the beginning of the growing season leads to inhibition of development and stress. Seedlings grow very slowly. Biochemical processes in plant tissues are disrupted. The strength of the cell walls decreases, the thickness of the cuticle decreases. In these conditions, they are especially susceptible to infection by pathogenic organisms.

Even with a low natural phytopathogenic background, infection on seeds is capable of forming epiphytoties at the beginning of the growing season. Exotic species of fungi infect tissues of weakened plants (at the stage of seedlings and seedlings). The accumulation of native species of infection in the lands adjacent to the fields during the cultivation period leads to the appearance of epiphytoties in the second half of the growing season. First of all, the assimilation apparatus, flowers, ovaries and fruits are affected.

Thus, when growing plants with short daylight hours at the northern border of the cultivation areas, it is necessary to take into account the ecological characteristics of pathogenic organisms. This will make it possible to correctly develop a crop protection system, prevent the spread of exotic species of fungi along with cultivated plants, and prevent the manifestation of epiphytoties of mycoses.

\section{References}

1. V.A. Chulkina, E.Yu. Toropova, G.J. Stecov. Integrated Protection of Plants: Phytosanitary Systems and Technologies (2009).

2. R.V. Davydov, M.S. Mazing, V.V. Yushkova, A.V. Stirmanov, V.Yu. Rud. A new method for monitoring the health condition based on nondestructive signals of laser radiation absorption and scattering, Journal of Physics: Conference Series, 1410(1), 012067 (2019). 
3. R. Davydov, M. Sokolov, W. Hogland, A. Glinushkin, A. Markaryan. The application of pesticides and mineral fertilizers in agriculture, MATEC Web of Conferences, 245, 11003 (2018).

4. A. Glinushkin, T. Akimov, O. Beloshapkina, M. Diuldin, J. Molnár. Fungicidal activity of seed disinfectants against root rot of wheat in various types of soils. IOP Conference Series: Earth and Environmental Science, 390(1),012015 (2019).

5. A.P. Glinushkin, V.I. Startsev, L.V. Startseva. Biological Aspects of Economic Efficiency of Crop Farming, IOP Conference Series: Earth and Environmental Science, 459(6),062069 (2020).

6. M.I. Kiseleva, A.V. Ovsyankina, T.M. Kolomiets, N.S. Zhemchuzhina, A.P. Glinushkin. Some aspects of the distribution of Fusarium on cereals of Russia, Acta Phytopathologica et Entomologica Hungarica. 51(2), c. 183-192 (2016).

7. A.N. Naliukhin, S.M. Khamitova, A.P. Glinushkin, O.V. Siluyanova, D.A. Belozerov Changes in the Metagenome of Prokaryotic Community as an Indicator of Fertility of Arable Soddy-Podzolic Soils upon Fertilizer Application. Eurasian Soil Science. 51(3), p. 321-326 (2018).

8. S.S. Sanin. Epiphytotics of Diseases of Grain Crops: Theory and Practice (2012).

9. V. Strel'Tsova, I. Podkovyrov, A. Sevryugina, Y. Spiridonov, A. Ovsyankina, A. Gerner. Defeat Fusarium fungi underground and aboveground system of wheat in the conditions of gray-forest and dark chestnut soils, IOP Conference Series: Earth and Environmental Science, 390, 1, (2019).

10. I.A. Zharikov, R.V. Davydov, V.A. Lyapishev, V.Y. Rud, Y.V. Rud, A.P. Glynushkin. Features of the induced photopleochroism oscillations in a photosensitive structures based on CuInSe ${ }_{2}$. Journal of Physics: Conference Series (2017). 